\title{
Implementasi Profile Matching untuk Rekomendasi Jenjang Karir Karyawan (Studi Kasus : PT. Fasic Indonesia)
}

\author{
Siti Yuliyanti ${ }^{1}$, Mira Mustika Febikusuma ${ }^{2}$ \\ ${ }^{1,2}$ Program Studi Sistem Informasi STMIK Bandung \\ Jln. Cikutra No. 113 Bandung, Jawa Barat Indonesia \\ Isitiyuliyanti@stmik-bandung.ac.id; sitiyuliyanti.stmikbandung@gmail.com \\ 2 miramustikaf@gmail.com
}

\begin{abstract}
Intisari- Teknologi Informasi dalam dunia industri dan bisnis Global yang memiliki fungsi sebagai Planning and Decision dimana teknologi informasi masuk ke tataran peran yang lebih strategis karena keberadaannya sebagai penyedia dari rencana bisnis perusahaan dan merupakan sebuah tambahan informasi bagi para pimpinan perusahaan yang dihadapkan pada realitas untuk mengambil sejumlah keputusan penting. Teknologi yang canggih tanpa diimbangi dengan Sumber Daya Manusia yang baik akan menjadi sia-sia. Pemilihan Leader atau pimpinan dari berbagai kandidat karyawan terbaik menjadi acuan yang objektif untuk menentukan pemimpin yang akan mengisi suatu posisi jabatan. Rekomendasi dari pimpinan atau rekan kerja untuk menilai karyawan yang akan menjadi pimpinan bukan suatu jaminan dan masih bersifat subjektif. Perlu ada perubahan cara dan metode sebagai alternatif pemilihan pimpinan yang sesuai dengan kebutuhan. Dalam penelitian kali ini metode Profile Matching menjadi pilihan guna memberikan penilaian dan evaluasi kinerja karyawan untuk dipromosikan menjadi Leader. Ada tiga aspek dalam melakukan penilaian dan evaluasi tersebut, yaitu Aspek Kecerdasan terdiri dari tingkat kreatif, penalaran dan solusi, gagasan ide, konsentrasi, dan antisipasi. Aspek Sikap Kerja memiliki unsur ketelitian, tanggungjawab, pengendalian perasaan, motivasi untuk berprestasi, perencanaan, kehati-hatian. Terakhir Aspek Perilaku meliputi kepatutan,
\end{abstract} Kesungguhan, mandiri dan dinamis.

Kata kunci_- kinerja, penilaian, karyawan, profile matching, jenjang karir.

Abstract - Information technology in the world of industry and global business which has a function as Planning and Decision where information technology enters a more strategic role because of its existence as a provider of company business plans and is an additional information for company leaders who are faced with the reality of making a number of decisions urgent. Sophisticated technology without being balanced with good Human Resources will be useless. The selection of a leader or leadership from the best employee candidates is an objective reference for determining the leader who will fill a position. Recommendations from leaders or colleagues to assess employees who will become leaders are not a guarantee and are still subjective. There needs to be a change in methods and methods as an alternative to selecting leaders according to needs. In this research, the Profile Matching method is an option to provide assessment and evaluation of employee performance to be promoted to Leader. There are three aspects in conducting the assessment and evaluation, namely the Intelligence Aspect consisting of the creative level, reasoning and solutions, ideas, concentration, and anticipation. Aspects of work attitudes have elements of accuracy, responsibility, feeling control, motivation for achievement, planning, prudence. Finally, the behavioral aspects include appropriateness, seriousness, independence and dynamism.

Keywords - performance, appraisal, employees, profile matching, career path.

\section{Pendahuluan}

Salah satu elemen dalam perusahan yang sangat penting adalah Sumber Daya Manusia (SDM). Pengelolaan SDM dari suatu perusahaan sangat mempengaruhi banyak aspek penentu keberhasilan kerja dari perusahaan tersebut. Jika SDM dapat diorganisir dengan baik, maka diharapkan perusahaan dapat menjalankan semua proses usahanya dengan baik. Terdapat beberapa kendala pengelolaan SDM, salah satunya adalah apabila perusahaan memiliki jumlah karyawan yang cukup banyak maka perencanaan jenjang karir dari tiap karyawan dan kaderisasi/pergantian jabatan dalam perusahaan menjadi sulit dan menghabiskan banyak waktu karena tiap-tiap personal Human Resource
Departement (HRD) belum tentu mengenal dengan dekat tiap karyawan yang ada, hal ini akan menjadi kendala yang cukup signifikan dalam rangka menyusun jenjang karir dari tiap karyawan dan kaderisasi/pergantian jabatan karena hal-hal tersebut harus dilakukan berbasis kompetensi dari tiap-tiap jabatan dan karyawan yang bersangkutan.[7]

Untuk memudahkan pelaksanaan kaderisasi dan jenjang karir dari tiap karyawan maka dibuat sebuah sistem program yang bertujuan memudahkan proses, penyusunan dan pengenalan target (dalam hal ini karyawan) dalam memudahkan penyusunan jenjang karir dan kaderisasi dari organisasi perusahaan. Sistem kompetensi akan mendeskripsikan prestasi dan potensi 
SDM sesuai dengan unit kerjanya. Pencapaian prestasi karyawan dan potensinya dapat terlihat apakah kompetensinya tersebut telah sesuai dengan tugas pekerjaan yang dimilikinya.Adapun kompetensi itu sendiri akan merupakan kombinasi dari pengetahuan, keterampilan, sikap, dan perilaku yang dimiliki karyawan agar dapat melaksanakan tugas dan peran pada jabatan yang diduduki secara produktif dan profesional disebut program P2K (Pemetaan Potensi Karyawan) sebagai usaha untuk memetakan potensi karyawan.

Tujuan penelitian ini adalah:

1. Menciptakan persaingan kerja yang sportif tanpa adanya kecurangan dalam proses pengangkatan karyawan dengan penilaian karyawan dilakukan oleh kepala bagian secara obyektif untuk menghindari unsur nepotisme, unsur kedekatan, serta money game dalam pengangkatan karir karyawan.

2. Menciptakan pemimpin di produksi yang memiliki kualitas kerja yang baik, serta menempatkan karyawan sesuai dengan kemampuan/skill.

3. Membantu dalam mempertimbangkan jenjang karir karyawan dalam program jangka pendek dan jangka panjang.

\section{Metodologi Penelitian}

Proses penelitiann ini diawalani dengan observasi dan menganalisis data yang ada di perusahan untuk di telusuri indicator mana saja yang dapat disesuaikan dengan metode yang digunakan. Setelah diperoleh indicator maka kita petakaan terhadap profil karyawan untuk mengetahui kecocokan dengan mengimplementasikan metode Profil Matching.

\section{HASIL DAN PEMBAHASAN}

Proses perhitungan pada metode Profile Matching, diawali dengan pendefinisian nilai minimum untuk setiap variabel-variabel penilaian. Selisih setiap nilai data testing terhadap nilai minimum masing-masing variabel, merupakan gap yang kemudian diberi bobot. Bobot setiap variabel akan dihitung rata-rata berdasarkan kelompok variabel Core Factor (CF) dan Secondary Factor(SF). Komposisi CF ditambah SF adalah $100 \%$, tergantung dari kepentingan pengguna metode ini. Tahap terakhir dari metode ini, adalah proses akumulasi nilai CF dan SF berdasarkan nilai-nilai variabel data testing. [4].

Jenjang karier atau tangga karier (career ladder) adalah jalur yang dilalui suatu karier ketika karyawan mencapai kemajuan ke posisi dengan tanggung jawab lebih besar. Karyawan dapat menapaki jenjang karier dalam satu organisasi atau beberapa organisasi.

Sasaran karier (career goal) adalah serangkaian pekerjaan dan peran hidup lainnya yang ingin diraih yang mengekspresikan komitmen kerja dan mencerminkan pola keseluruhan pengembangan diri. [3]

\section{Penilaian Kinerja}

Penilaian terhadap prestasi pekerjaan dapat diklasfikasikan ke dalam dua tipe umum yaitu Tipe Obyektif dan Tipe Subyektif. Dalam penilaian prestasi pekerjaan tipe obyektif misalnya memasukan data produksi atau pemasaran. Tipe obyektif yang memiliki berbagai faktor 'nir-kendali' sebaiknya tidak diterapkan secara mutlak dan teoritis. Pendekatan-pendekatan praktis dan subyektif dapat dimasukan sebagai bahan pertimbangan dalam penilaian. Beberapa hal yang kurang menguntungkan dalam tipe obyektif membuat para peneliti dan manajer lebih menekankan pada penilaian tipe subyektif terhadap prestasi kerja karyawan [6]

Salah satu metode penilaian kinerja karyawan yaitu proses profile matching. Profile matching adalah sebuah mekanisme pengambilan keputusan dengan mengasumsikan bahwa terdapat tingkat variabel prediktor yang ideal yang harus dimiliki oleh pelamar, bukannya tinggkat minimal yang harus dipenuhi atau dilewati [9] Dalam proses profile matching secara garis besar merupakan proses membandingkan antara kompetensi individu kedalam kompetensi jabatan sehingga dapat diketahui perbedaan kompetensinya (disebut juga gap), semakin kecil gap yang dihasilkan maka bobot nilainya semakin besar yang berarti memiliki peluang lebih besar untuk karyawan menempati posisi tersebut.

Untuk menganalisis karyawan yang sesuai dengan jabatan tertentu dilakukan dengan metode profile matching, dimana dalam proses ini terlebih dahulu menentukan kompetensi (kemampuan) yang diperlukan oleh suatu jabatan. Dalam proses profile matching secara garis besar merupakan proses membandingkan antara kompetensi individu ke dalam kompetensi jabatan sehingga dapat diketahui perbedaan kompetensinya (disebut juga gap).[4]

Proses ujian peningkatan kemampuan karyawan dilakukan secara manual, belum menggunakan sistem yang terkomputerisasi baik aplikasi berbasis desktop maupun aplikasi berbasis website. Semua proses ujian peningkatan kemampuan karyawan dilakukan secara konvensional melalui tatap muka langsung kepada pihak pengawas atau dengan cara penilaian manual sepihak dengan metode rating scale. Dimana proses yang biasa dilakukan yaitu dengan cara menilai karyawan berdasarkan penilaian kedekatan karyawan dengan beberapa petinggi di perusahaan.

Adapun untuk penilaian karyawan lain diberikan masingmasing angka sebagai nilai secara manual untuk menentukan grade $\mathrm{A}, \mathrm{B}, \mathrm{C}$, atau $\mathrm{D}$ dimana nilai dari A B $\mathrm{C}$ D tersebut mempunyai nilai tertentu. Jika karyawan dinyatakan sudah layak ke tingkat selanjutnya maka karyawan akan mendapatkan penilaiannya.[2]

Analisis fungsionalitas dilakukan supaya dapat mengetahui apakah sistem mampu melakukan proses penilaian secara bertahap dengan cara :

a. Melakukan proses penilaian sebanyak 2 tahap, dengan tiap tahapan mendapatkan 5 poin.

b. Penilaian dilakukan selama 3 bulan untuk menentukan kriteria karyawan terbaik

Analisis teori merupakan analisis seperangkat konsep atau konstruk, definisi dan proposisi yang berusaha menjelaskan hubungan sistimatis suatu fenomena, dengan cara memerinci hubungan sebab - sebab dan akibat yang terjadi. 
Analisis teori dilakukan supaya dapat mengetahui bagaimana alur proses penilaian peningkatan karyawan, dengan cara :

a. Karyawan menunjukkan kinerja kerja yang baik selama proses 3 bulan penilaian, dengan karyawan tidak diberitahukan sebelumnya bahwa akan ada penilaian kerja karyawan.

b. Penilaian juga disistemkan menjadi 2 tahap, yaitu tahap Core Factor dan Secondary Factor.

\section{Penilaian Core Factor atau Faktor Utama}

Core Factor merupakan pengambilan beberapa kriteria dari masing-masing aspek yang paling utama dan nantinya akan dijadikan sebagai core factor atau faktor utama dalam penilaian. Kriteria-kriteria yang termasuk ke dalam kriteria penilaian core factor sendiri terdiri dari kriteria aspek penilaian, antara lain pengalaman kerja, keahlian kerja, kedisiplinan, penguasaan tentang proses produksi, kemampuan dalam memecahkan masalah di produksi, cara berfikir dan tanggung jawab.

Berikut adalah cara menghitung Core Factor:

$$
\mathrm{NFC}=\frac{\mathrm{NC}}{\mathrm{IC}}
$$

$\mathrm{NFC}=$ Nilai rata-rata Core Factor

$\mathrm{NC}=$ Jumlah total nilai Core Factor

$\mathrm{IC}=$ Jumlah item Core Factor

\section{Penilaian Secondary Factor}

Sedangkan Secondary Factor adalah penilaian yang merupakan sisa dari kriteria yang bukan termasuk kriteria penilaian utama atau core factor. Kriteria dari secondary factor juga terdiri dari beberapa kriteria penilaian yang diantaranya adalah penilaian absensi/kehadiran, kebersihan lingkungan kerja, pencapaian target produksi, cara kerja, ketangkasan dalam bekerja, kemampuan dalam team dan kesopanan. Berikut cara menghitung Secondary Factor:

$$
\text { NFS }=\frac{\text { NS }}{\text { IS }}
$$

NFS = Nilai rata-rata Secondary Factor

$\mathrm{NS}=$ Jumlah total nilai Secondary Factor

IS = Jumlah item Secondary Factor

Perhitungan nilai total dari nilai Core Factor \&Secondary Factor.

$$
\mathrm{NSP}=(\mathrm{x}) \% \mathrm{NCF}+(\mathrm{x}) \% \mathrm{NSF}
$$

NSP $=$ Nilai Total dari kriteria dalam Satu Periode $\mathrm{NFC}=$ Nilai rata-rata Core Factor NFS = Nilai rata-rata Secondary Factor (x) $\%=$ Nilai persen yang diinputkan

Setelah selesai penilaian, maka nilai akan diolah sesuai dengan hasil kinerja karyawan bekerja selama 3 bulan menjadi penentuan penilaian ranking.

$$
\text { Ranking }=\frac{\mathrm{NSP}_{1}+\mathbf{N S P}_{2}+\mathrm{NSP}_{3}}{\mathrm{JP}}
$$

$\mathrm{NSP}_{1}=$ Nilai total kriteria Periode Pertama

$\mathrm{NSP}_{2}=$ Nilai total kriteria Periode Kedua

$\mathrm{NSP}_{3}=$ Nilai total kriteria Periode Ketiga

$\mathrm{JP}=$ Total Jumlah Periode

Dalam sistem ini terdapat 3 posisi jabatan yang memiliki kriteria penilaian yang berbeda-beda dari tiap posisi yang akan direkomendasikan untuk diisi, antara lain:

a. Chief/Kepala Bagian, kriteria yang harus diisi antara lain pengalaman kerja, keahlian kerja, kemampuan dalam menyelesaikan masalah dan pemahaman proses produksi menyeluruh, kecerdasan dan kesopanan.

b. Supervisor, kriterianya antara lain keahlian kerja, lamanya masa kerja, ketangkasan dalam bekerja, cara kerja dan kebersihan tempat kerja.

Pengawas, kriteria untuk jabatan ini antara lain kedisiplinan, kehadiran, kesopanan, kemampuan dalam team, tanggung jawab, pencapaian target. Proses penilaian akhir dapat dilihat pada Tabel 1.

Tabel 1.

Hasil proses penilaian akhir

\begin{tabular}{|c|c|c|c|c|c|c|}
\hline No. & $\begin{array}{c}\text { ID } \\
\text { Kary }\end{array}$ & $\begin{array}{c}\text { Nilai } \\
\text { Bulan } \\
1\end{array}$ & $\begin{array}{c}\text { Nilai } \\
\text { Bulan } \\
2\end{array}$ & $\begin{array}{c}\text { Nilai } \\
\text { Bulan } \\
3\end{array}$ & Nilai Akhir & Ranking \\
\hline 1 & IM & 9.92 & 9.84 & 10 & 9.92 & 1 \\
\hline 2 & TR & 9.48 & 9.20 & 10 & 9.56 & 2 \\
\hline 3 & YH & 8 & 8 & 8 & 8 & 3 \\
\hline
\end{tabular}

Implementasi Metode Profile Matching pada aplikasi

Sebelum memulai penilaian setiap pengguna akan login pada antarmuka sebagaimana terlampir pada Gambar 3.

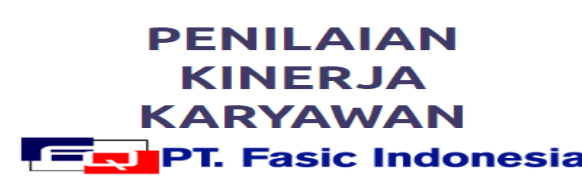

LOGIN

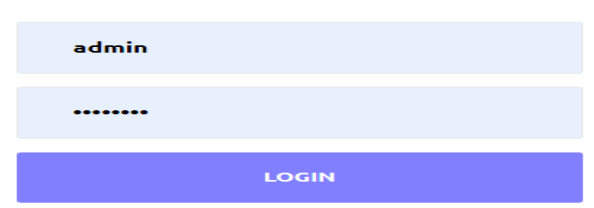

Gambar 1. Tampilan Antar muka

Setelah login pengguna harus memastikan tebal kriteria sudah sesuai dengan data yang akan dipetakan menggunakan profile matching dan kriteria penilaian dapat dilihat pada Gambar 2. Kemudian membuka periode penilaian dan mengisi nilai kriteria penilaian masing-masing karyawan sepesrti terlampir pada Gambar 3. 


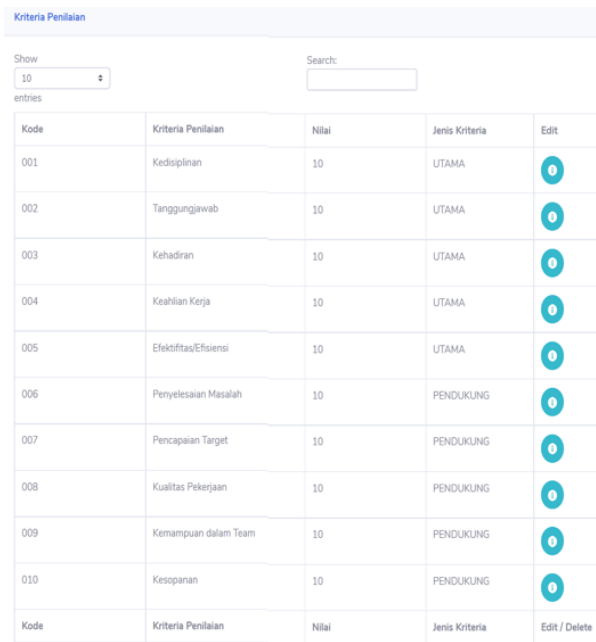

Gambar 2. Kriteria penilaian

Untuk input penilaian karyawan pada data kriteria, sistem memberikan range atau batasan nilai minimum adalah 0 dan nilai maksimum adalah 10 . Maka nilai 0 dan 10 akan membentuk nilai batas. Jika setiap nilai yang diinputkan di bawah 0 atau di atas 10 akan dianggap tidak valid sehingga menghasilkan hasil akhir hitungan yang tidak sesuai dengan nilai yang diinputkan dan akan terjadi error pada sistem, kondisi ini disebut dengan negative testing. Tetapi sebaliknya, jika setiap nilai yang diinputkan di atas 0 dan di bawah 10 maka akan dianggap valid atau biasa disebut dengan positive testing.

Kasus dan hasil pengujian ini dilakukan untuk mengetahui hasil dari rancangan aplikasi yang akan diimplementasikan apakah sudah berfungsi dengan baik atau belum, hal ini juga berfungsi untuk mengetahui kekurangan-kekurangan dari sistem yang diusulkan.

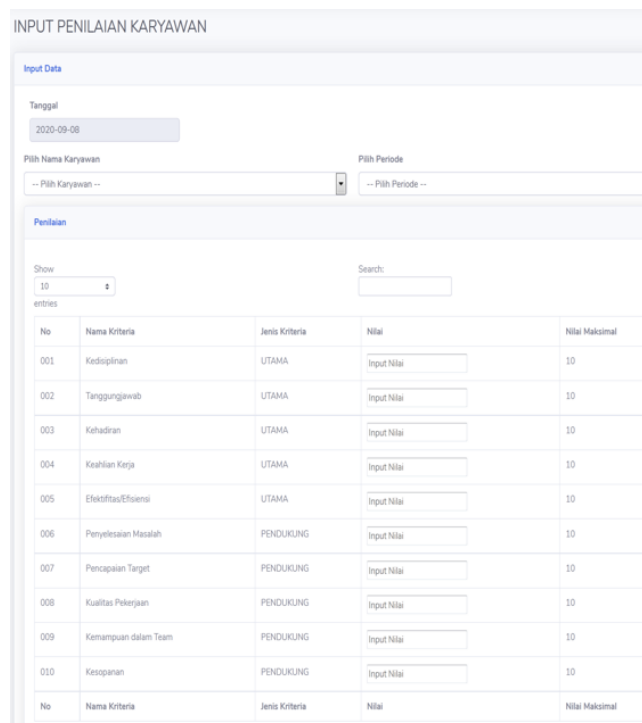

Gambar 3. Input nilai kriteia penilaian

Sehingga dapat muncul hasil pemetaan nilai profil setiap karyawan dengan standar nilai pada kriteria penilaian untuk jenjang karir. Sebagaimana terlampir pada Gambar 4. Dan akan ditentukan jenajng karir berdasarkan nilai akhirnya semakin besar maka semakin cocok atau matching untuk karyawan tersebut naik jabatam.
Penilaian jenanga karir karyawan akan dinilai setiap bulannya sehingga dapat diakumulasi tergantung permintaan atasan. Biasanya pertahun dapat diakumulasi Kembali, jika ada jabatan yang kosong maka dapat diakumulasi missal 3 bulan atau tergantung kebutuan seperti pada Gambar 4.

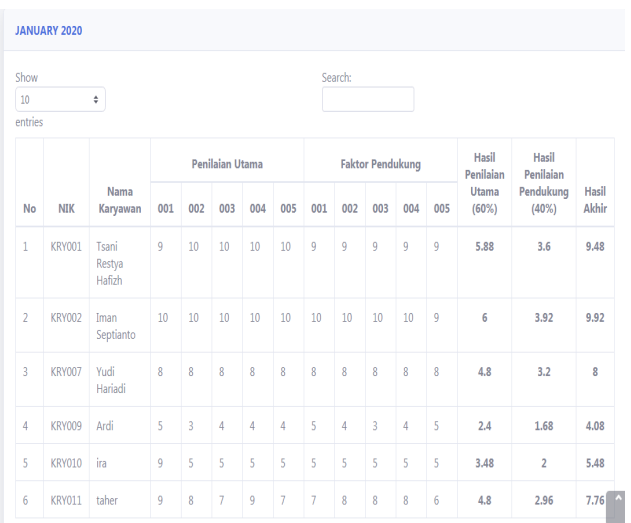

Gambar 4. Pemetaan nilai kriteia penilaian setiap karyawan

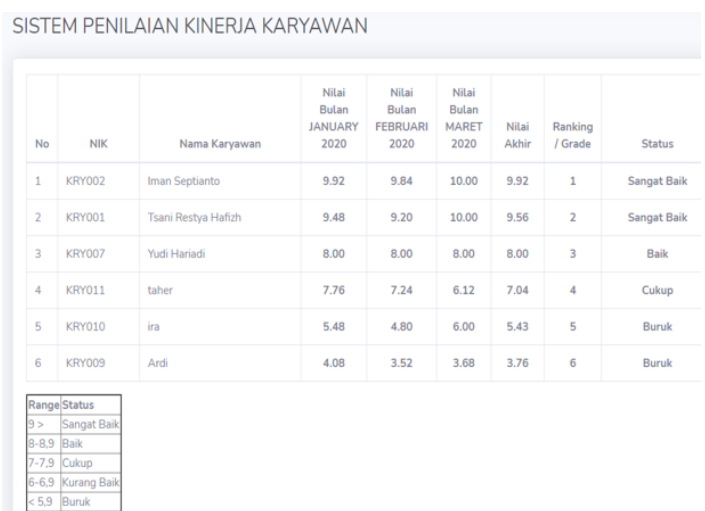

Gambar 2. Hasil Akhir Penilaian dan Grade dari setiap akumulasi nilai

Kasus dan hasil pengujian ini dilakukan untuk mengetahui hasil dari rancangan aplikasi yang akan diimplementasikan apakah sudah berfungsi dengan baik atau belum, hal ini juga berfungsi untuk mengetahui kekurangan-kekurangan dari sistem yang diusulkan.

\section{Kesimpulan}

Metode Profile Matching dapat direkomendasikan sebagai salah satu alternatif yang dapat membantu dalam pengambilan keputusan. Terutama dalam kegiatan organisasi dan manajemen sumber daya manusia, sumber daya manusia yang baik akan berdampak positif untuk perkembangan dan kemajuan organisasi atau perusahaan. Berikut kesimpulan yang didapat dari proses analisis, perancangan dan implementasi sistem :

1. Karyawan mendapatkan informasi penilaian melalui web secara jelas.

2. Proses penilaian dilakukan secara otomatis oleh sistem agar menghasilkan nilai yang akurat. 
UCAPAN TERIMA KASIH

Apresiasi penyusun sampaikan kepada Civitas akademika STMIK Bandung, PT. Fasic Indonesia, keluarga dan seluruh rekan serta teman yang berkontibusi baik langsung atau tidak langsung sehingga penelitian ini dapat diselesaikan.

\section{REFERENSI}

[1] L. Al-Bahra, Analsisi dan Desain Sistem Informasi, Yogyakarta: Graha Ilmu, 2005.

[2] B. S. Dharma, Perencanaan dan Pembangunan Sistem Informasi, Yogyakarta: Andi, 2002.

[3] H. Pratiwi, Sistem Pendukung Keputusan, Yogyakarta: Deepublish, 2016.

[4] T. Sutabri, Analisis Sistem Informasi, Yogyakarta: Andi, 2004.

[5] M. S. Al-Farizi and S. Yuliyanti, "Sistem Informasi Penilaian Karyawan menggunakan Key Performance Indicator," Jurnal Teknologi Informasi dan Komunikasi
(JURTIK), vol. 9, no. 1, pp. 22 - 29, 2019.

[6] S. Yuliyanti, D. P. Kartaputra and A. S. Usman, "Sistem Pendukung Keputusan Penentuan Calon Karyawan Tetap Menggunakan Metode Smart ( Studi Kasus : PT. Ajinomoto)," Jurnal Teknologi Informasi dan Komunikasi (JURTIK), vol. 7, no. 1, pp. 49 - 57, 2008.

[7] E. Turban, Decision Support and Expert System, New York: Mac Millan, 1998.

[8] M. Fauzi, "Implementasi Gap Profile Matching pada Sistem Pendukung Keputusan dalam menentukan Kenaikan Level pada Karyawan PT. Long Sun Indonesia," in Prosiding Seminar Nasional Informatika (SNIf), medan, 2015.

[9] L. Tanti, "Analisis Promosi Kenaikan Jabatan Berdasarkan Evaluasi Kinerja Pegawai," Creative Information Technology Journal, Universitas AMIKOM Yogyakarta, vol. 3, no. 4, pp. 331 - 343, 2016. 